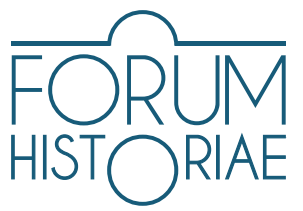

\title{
The Genesis of Political Distrust Towards the "Sixty- Eighters" in Czech Politics Over the Course of 1989
}

\author{
Kristina Andělová
}

\begin{abstract}
ANDĚLOVÁ, Kristina. The Genesis of Political Distrust Towards the "Sixty-Eighters" in Czech Politics Over the Course of 1989.

This article focuses on the genesis of political distrust against the so-called sixty-eighters-former reform communists-after 1989, outlining in detail the political trajectories of the Prague Spring communist actors. These politicians - the so-called socialist opposition-represented an important part of the Czechoslovak democratic opposition in the 1970s and 1980s. Even though many of the reform communists also stood at the inception of Charter 77, non-communist dissent was politically distrustful of the socialist opposition, centred around the journal Listy. Unlike the "non-political" Charter 77, Czechoslovak socialist opposition has always advocated for a profiled political program of democratic socialism. Thus, this distrust towards the reform communists persisted after 1989. In a situation where Marxism and socialism had completely lost political power and much of society rejected the socialist left as a dangerous remnant of the communist dictatorship, the advocates of post-communist democratic socialism found themselves on the margins of political discourse.
\end{abstract}

Keywords: Prague Spring, political distrust, reform communism, Czechoslovak dissent, Zdeněk Mlynář, Obroda, post-communism

DOI: https://doi.org/10.31577/forhist.2021.15.2.7

$\mathrm{H}$ istoriographical discussions of roughly the past fifteen years have opened questions regarding the nature of the events of 1989 and the so-called Velvet Revolution, doubting its purely liberal interpretation-one that regards the central political values of 1989 as liberal-democratic. In Czech and Slovak historiographical circles, this debate has taken place primarily around a book by American historian James Krapfl, Revolution with a Human Face. ${ }^{1}$ Krapfl points out that a key political concept related to the forming of civic society was that of democratic socialism, which is instinctively connected with the year 1968. Though for many involved, the idea of a return to the time of the Prague Spring might have been perceived as hope for a democratic future, if we look at the life stories of the people who are linked with reform communism, the so-called sixty-eighters, ${ }^{2}$ it is clear that after 1989 , a large portion of them were left

This study is a product of research funded by the Czech Science Foundation, research project "Czech Left Exile 1968-1989" (Český levicový exil 1968-1989”), registration number 20-11867S.

1 KRAPFL, James. Revolution with a Human Face: Politics, Culture and Society in Czechoslovakia after 17 November 1989. Bratislava: Kalligram, 2009; Published in Czech in 2016 as KRAPFL, James. Revoluce slidskou tvárí. Politika, kultura a společenství v Československu v letech 1989-1992. Prague : Rybka Publishers, 2016.

2 The term "sixty-eighter" is somewhat problematic, because there is no clear definition of who exactly falls into this category and who does not, yet the term is used quite commonly in Czech historiography and journalism, especially as a label for a group of politically active individuals who vigorously supported reform communist efforts in the 1960s, as well as Dubček and the Action Programme during the Prague Spring (many of them took part in its creation). They were a part of the post-war generation, which was united by notably similar, frequently shared life experiences. Born mostly in the mid-1920s, they shared an adolescence strongly marked by the economic crisis, the Munich Agreement and the occupation of Czechoslovakia. These experiences were hugely important in shaping the political attitudes of this generation. The so-called 
standing in the wings of political events. Even though many of these people played significant roles in the realization of Charter 77 or otherwise supported dissident activities, public discourse after 1989 did not accept them as credible representatives of the emerging political democracy. In the following text, I will attempt to reveal the historical genesis of political distrust towards the sixty-eighters and its manifestation early in the decade of the 1990s.

The idea of social equality, which lay at the core of the communist project, lost all legitimacy after 1989 and in contrast, the previously "asocial" understanding of the concepts of individual performance, competition or austerity (Klaus's "belt-tightening") acquired a new moral strength. This led to discussion of capitalism in ethical terms and market principles were, with time, even seen as being more socially just. The supporters of market economics did not understand the concept of the market only in fiscal terms nor promote market mechanisms only in the economic field, but also in the development of cultural and social values. One of the most prominent advocates of the market as a fundamental democratic value was philosopher Václav Bělohradský, at that time an apologist for Václav Klaus, who stated that "the market for ideas, the dispute over the meaning of our interests and goals, are also a part of democracy, our aims are reasonable when they can compete in a market of ideas where people criticise everything". ${ }^{3}$ Bèlohradský rejected any effort to establish a political programme founded on any higher ideas of redemption or truth, as is revealed in the criticism of Marxist intellectuals (e.g. Kosík, Sviták), ${ }^{4}$ particularly in the effort to define themselves in relation to the market as a new form of tyranny. He rejected the idea that party dictatorship would be replaced by market dictatorship ${ }^{5}$ and on the contrary, accused left-wing intellectuals with an emphasis on politics of echoing the call for strong authority by saying that they "despair of being left without a master". ${ }^{6}$ In Bèlohradskýs opinion, the market was supposed to be liberating from any oppression or power, "the market economy [...] was an opportunity for culture to be one of the areas of free private enterprise, and thus to be without a master."

The period of the Prague Spring is generally considered as a few months of unification of Czechoslovak society in the name of democratising reform of the political system and support for Dubček's leadership. Certainly, the feeling of hope that the change in the Communist Party of Czechoslovakia (KSČ) leadership brought cannot be doubted, but it is also evident that the narrative of unanimous support for the project of reform communism is a bit more complicated. This was inspired mainly by the attitude of the reform communist establishment towards the spontaneous manifestations of civic activism in 1968. Ivan

\footnotetext{
"Munich complex" and a distrust towards liberal democracy persisted in these people virtually until the end of their lives, although the political situation around the group changed dramatically over many decades. During the occupation of Czechoslovakia and the Second World War, many of them were part of the anti-Nazi resistance, where they became acquainted with communist ideas for the first time (for example, in the resistance organisation Předvoj). After the war, or after 1948, they enthusiastically joined the Communist Party and supported its policies, sometimes rising to important political and social positions, often very quickly and at a relatively young age. They actively participated in the Stalinisation of Czechoslovak society. The name "reform communists" was given because after the "Thaw" in 1956, they initiated an attempt to de-Stalinise the Communist Party and democratise the regime during the 1960s. In the second half of the decade, or during the spring of 1968, they held important social positions and took part in the democratisation of the communist regime "from above", i.e., through reform of the Communist Party itself. This was best documented by the so-called Action Programme of April 1968.

4 BĚLOHRADSKÝ, Václav. Antiduch na Karlově mostě. In Literární noviny, 1992, Vol. 3, No. 44, p. 1.

5 BĚLOHRADSKÝ 1992.

6 BĚLOHRADSKÝ 1992

7 BĚLOHRADSKÝ, Václav. Trh a duchovní hodnoty. In BĚLOHRADSKÝ 1992, pp. 43-45.
} 
Sviták summed up the conflict symbolically in his famous article Vaše nynějš́ krize (Your Current Crisis) in April 1968, when Czechoslovak society felt itself to be on the verge of achieving the much-desired socialist democracy. Sviták pointed out the restrictive limits of this "democratic dream" by posing a provocative and fundamental question regarding the reform project: "Do the six million citizens-non-party members-of this country have the same political rights as members of the Communist Party or are they only being given a greater dose of freedom that does not threaten the privileges of party members?"8 The memory of the Prague Spring attached to the activities of people who later became known as the sixty-eighters is thus not only a memory of "nationwide" support for Dubček's leadership, it also shows scepticism towards the reform communist elites who in a certain moment of civic activism, turned against the independent expressions of social participation:

From the very beginning of the Prague Spring, it was clear that the political establishment was not inclined towards the emergence of any non-communist opposition. In March 1968, lawyer and politician Zdeněk Mlynár commented on the oft-discussed question of the National Front: [The National Front is] a political platform that does not divide political parties into a "government" and "opposition" in the sense that it would create an opponent pursuing power over the state. On the contrary, it posits the problem of a dispute over the line of state policy, including the issue of potential opposition to the position of one element against another on the grounds of a common agreement and common principles of the socialist conception. We ruled out opposition to this notion of the National Front back in $1945 .{ }^{9}$

Further, the considerably negative position towards the non-communist opposition was not only a theoretical postulate of reform communism, but it was also significantly relevant for party tactics against the possibility of renewing the Social Democratic Party in $1968 .{ }^{10}$ Reform communism saw the restoration of social democracy not as a manifestation of society's democratisation and the reinstatement of plurality, but as a failure in the process of merging social democracy with the Communist Party of Czechoslovakia (KSČ), which was a prerequisite for the functioning of communist society. ${ }^{11}$

The impossibility of political plurality outside the realm of the "socialist consensus" was a relatively clear political boundary that reform communism never questioned. This was a distinctive feature that began to emerge abruptly, especially in May 1968 after the de facto removal of censorship when critical views on the approach of the Communist Party and the Action Programme proliferated in the press. A defence mechanism of the reform communists produced a series of warnings against "anti-socialist and anti-communist forces" in society, which disrupted the otherwise unified reform process. For example, on 14 May 1968, the leading Czechoslovak macroeconomic analyst, Zdislav Šulc, wrote in Rudé právo (Red Justice) of the danger posed by anti-socialist elements and the need for national unity

8 SVITÁK, Ivan. Vaše nynější krize. In Student, 1968, Vol. 4, No. 18, p. 1.

9 MLYNÁŘ, Zdeněk. Co dál s naší demokracií? In Rudé právo, 26 March 1968, p. 3.

10 PECKA, Jindřich - BELDA, Josef - HOPPE, Jiří. Prameny k dějinám československé krize v letech 1967-1970, 2. díl, 2. svazek: Sociální organismy a hnutí Pražského jara. Prague; Brno : ÚSD; Doplněk, 1998, pp. 66-72.

11 A document for internal use of the party, "Report on the State of Renewal of the Social-Democratic Party and Proposals for Policy Measures", written by Zdeněk Mlynář, Evžen Erban and Bohumil Šimon (their report to the presidency of the Central Committee of the Communist Party) demonstrates the unwillingness of the reform leaders in the Communist Party towards the renewal of any non-communist opposition. The aim of the document was to prepare a process for preventing the establishment of social democracy by legal means. It is evident that the "restoration of the bourgeois party" would go far beyond cautious, conceptual proposals for the existence of another party. 
of all "progressive forces in Czechoslovakia". ${ }^{12}$ In presenting the activities of the ideological department of the Central Committee of the Communist Party, chairman Jan Kozel described the situation in Czechoslovakia as a "boiling ideological-political cauldron".13 Although Kozel appealed to the both communists and non-communists in an effort to participate in political development together, at the same time he pointed out the diversity and contradiction of ideas that were surfacing in the public ${ }^{14}$ and emphasised that it was impossible to close one's eyes even to the fact that, along with seeking a way and formulating ideas on a socialist basis, anti-socialist and anti-communist "glorifications of bourgeois democracy" are appearing. ${ }^{15}$

\section{The Formation of Reform Communist Opposition and the Magazine Listy}

The theory and practice of reform communism was an inseparable part of the Prague Spring and was certainly its driving force at the start. Over time, however, the reform communists became more and more opposed to a spontaneous social movement that did not respect the party boundaries of public demonstrations and therefore came into conflict with the reformist vision of politics. Through the course of the Prague Spring, political positions were gradually emancipated, meaning the reform communist programme was unable to solve basic systemic deficiencies.

This exclusive stance towards non-communist political thinking and activities that were not controlled by the party was fully communicated after the August invasion with the first attempts to "normalise" social conditions and limit proceedings that did not derive their authority from the Action Programme and the Party. Distrust of the reform communist establishment arose from the fact that after the removal of the sixty-eighters from public functions, they made only minimal efforts to support non-socialist or independent opposition yet continued to work in the relatively exclusive concept of "party" opposition. This can be observed from the political negotiations at the beginning of 1970s, during establishment of the magazine Listy (Letters), the most important media outlet of the so-called socialist opposition.

A "narrower organism", the so-called Listy group, was made senior to the editorial committee of Listy. It was an informal grouping, however, the members were at first leaders of the Communist Party who went into exile after the Soviet invasion (originally five functionaries who were co-opted into the party's Central Committee at the Congress of Vysočany one day after the Warsaw Pact Invasion-aside from Jiří Pelikán, they were Zdeněk Hejzlar, Ota Šik, Eduard Goldstücker and Jiři Pokštefl). ${ }^{16}$ It was in this close circle of intellectuals that the first dispute about the nature of opposition activities arose, following correspondence between Jiř́ Pelikán and Ota Šik. Immediately at the start of discussions on the direction of Listy, Sik expressed his disagreement with the mere confirmation of the validity of the Prague Spring without any more principled self-criticism or theoretical distancing from Marxism-Leninism. At the end of 1970, he wrote that in the future:

12 ŠULC, Zdislav. Komunisté a ti druzí. In Rudé právo, 15 May 1968, p. 2.

13 KOZEL, Jan. O aktuálních otázkách současné ideově politické práce. In Rudé právo, 16 May 1968, p. 3.

14 KOZEL 1968, p. 3.

15 KOZEL 1968, p. 3.

16 CACCAMO, Francesco. Jiří Pelikán a jeho cesta socialismem 20. století. Brno : Doplněk, 2008, p. 41. 
I will restrain from any political activity that could, in the non-communist members of our nations, cause doubts about our negative attitude towards the very basic principles on which the communist movement still stands, i.e. on the dictatorship of the proletariat, the leading role of the Communist Party, the rejection of pluralist democracy, the nationalisation of all means of production, the state directive planning of the economy, the rejection of the market under socialism, the denying of corporate self-government $[\ldots]$ etc. ${ }^{17}$

Šik appealed for a new opposition strategy to include not only reform communists, but also representatives of other political forces in exile that had been organised during the Prague Spring such as the Social Democratic Party, the Club of Committed Non-Party Members (KAN) or Klub 231 (K231).

This stance, however, provoked considerable objection from Listy's leadership. Zdeněk Hejzlar, former director of Czechoslovak Radio, labelled Šik's concept "misguided" and stated that the Social Democrats, KAN and K231 were not "trustworthy partners" for the Listy group and that some of their representatives in exile "took positions incompatible with the communist ideology". In agreement with the other leaders of Listy, Hejzlar believed that the most effective political strategy for how to "strike" Brezhnev and deny the right of Husák's new leadership to pass themselves off as the only spokesperson for the Communist Party was to act not as a politically murky civic opposition, but as a thoroughly communist platform:

Our output must be [...] only and only the party and speak on behalf of the silenced delegates of the actual 14th [Vysočany] Congress and speak only the language of the resurgent party as it was formed before this Congress. ${ }^{18}$

In this sense, the reform communists also spoke about the so-called party of the excluded, and in this regard, clearly considered themselves to be legitimate representatives and therefore should enjoy the respect of a large part of Czechoslovak society. Although this "party of the excluded" was meant to represent an opposition, it was not an independent opposition made up of different channels of thought but organised and conscious former party members. It was supposed to be about "hundreds of thousands of relatively young people with great political experience and awareness of the alternative socialist programme, raised within the party and the system and therefore easily orientated, with innumerable and imperceptible relationships with those who remained in the party and system". ${ }^{19}$

The result of the debate within Listy on the nature of their opposition was at first the homogeneity of the group, where the idea of ideological continuity prevailed, with the project of reform communism and with the party strategy of political struggle. As such, reform communism was unable to relinquish its ties with party structures. The theoretical basis

17 Šik to Pelikán from the end of 1970 (undated). Cited according CACCAMO 2008, p. 42.

18 Hejzlar to Pelikán, 2 March 1971. Cited according CACCAMO 2008, p. 42.

19 Šik rejected an "exclusive" strategy conceived as such. His views in this dispute did not wane but rather became more radicalised, leading to limited future involvement in the "letters" of socialist opposition. Once again, the principle question of political plurality and its limits, the question of non-party participation in political life, returned to reformist communist thinking and did so in the limited space of the anti-normalisation opposition. Before his departure from the Listy group, Sik even wrote, "The people have the right not only to choose a form of socialism, but also a social form in general! Perhaps after all the terrible experiences they may not want socialism after all-I hope not and that the forces for democratic socialism will be greater. However, today we do not have the right to decide this debate in advance." Sik's position was not made public in the end "for strategic reasons"so that the socialist opposition would not expose internal resentment, which would jeopardise the effort to act as "heirs of the sixty-eighters"-and his cooperation with Listy began to decline. See CACCAMO, 2008, p.44. 
of reform communism lay in the macro-political belief of the "old left", namely that in order for political change to be successful, it must happen at the systemic level-under the control of state and party institutions through which political acts are to be pursued ${ }^{20}$ In this respect, the categories of "independent thinking" or "parallel structures" for reform communism were difficult to integrate, as was equally the idea of a micro-political opposition struggle, which proceeded independently of the state or even as an individual protest against society (most famously articulated by Vaclav Havel in his Power of the Powerless). For reform communism, the question of power did not lie in the potential subversion or disruption of hegemony, power was linked with access to political decision-making and control of state and party institutions.

\section{Reform Communists in Relation to Charter 77 and the Non-Communist Opposition}

Often the high number of reform communists-so-called ex-communists-active in the early days of Charter 77 is emphasised, yet from the standpoint of their original interest in mobilising tens of thousands of expelled communists, the over one-hundred signatures were actually more a sign of the lethargy of those who demonstrated their activism as party members in 1968. The legacy of reform communist thought in Charter 77 resonated in different forms, above all thanks to leading political thinkers-Zděněk Mlynár and Jiří Hájek-who stood by the birth of the Charter 77 initiative itself. Although, in their eyes, it brought a new concept of the criticism of power, they certainly also saw it as an activity that embodied continuity both with 1968 and the activities of the socialist opposition in the first half of the 1970s. In this regard, leading reform communists in the opposition rightly perceived the Charter as a not wholly innovative document. Mlynár pointed out that:

Everything that was written in Charter 77 has been written and said many times before. Testimonies on discrimination are generally well known both at home and abroad. In fact, it did not much present any new problem. In a specific situation and in a slightly different way it only presented a long-known problem. ${ }^{21}$

No consensus prevailed among the reform communists in the opposition on cooperating with non-communists and departing from the "Prague Spring Line"; the group itself was too diverse to take a unified approach. The ex-communists were divided by several opinion streams, which differed primarily in their relationship to the possibility of political rehabilitation-and perhaps also the reintegration into political structures, but also in their views on the methods of political action in Czechoslovakia. In the context of establishing Charter 77 and regarding the relationships with the non-communist opposition, it is possible to speak about three main—but mutually linked—directions within the reform communist post-August orientation.

The first was defined by hope for reintegration into political power structures. The idea of a certain type of "Kádárization" of Czechoslovakia, according to the Hungarian style, with a partial reform programme of political democratisation reigned here. Čestmír Císar̆ or Oldřich Černík, for example, can be placed among the leading representatives of this

20 BARŠA, Pavel. Cesty k emancipaci. Prague : Academia, 2015, p. 187.

21 Mlynár further writes: "So if on 7 January 1977 (when the text of Charter 77 was published abroad) the government faced only one more of the many previous protests by discriminated citizens, today it has an altered domestic political situation - and not in favour of its own, longer-term intentions and needs. But it has certainly caused this itself.” MLYNÁ ̌̌, Zdeněk. První bilance Charty 77. In Listy, 1977, Vol. 7, No. 2, p. 3. 
direction and for the most part, it was characterised by a critical or distant position regarding Charter 77 and the non-communist opposition. ${ }^{22}$ With respect to abandoning Leninist positions and the liberal "conversion" of some former party members, Císař spoke about the "tragedy of Czechoslovak progressivism" and labelled former reform communists who questioned the development of Soviet socialism "apostates". ${ }^{23}$ When Mlynář̀s publication Mráz přichází z Kremlu (Nightfrost in Prague: The End of Humane Socialism) was later published, some passages sparked a critical discussion within this reform communist channel. One of the most critical reactions came from Čestmír Císař, describing the book as "a document convicting its author of full personal and social surrender to the difficulties of world socialism" ${ }^{24}$ In his opinion, Mlynár is no longer concerned with "the development of the Soviet establishment by means of reforms towards truly prosperous socialism", ${ }^{25}$ but is making a "cross" over the Soviet establishment and "has no choice in his next book but to go over to the platform shared by the anti-communists". ${ }^{26}$

The second line of opinion regarding Charter 77 was comprised of people who believed that the views of reform communism and the legacy of the Action Programme from 1968 should be the ideological foundation for unity of an opposition movement in Czechoslovakia, and that retreating from their positions may mean the future fragmentation of the socialist structures of society acquired in the past. Alexander Dubček, who throughout the period of normalisation maintained a certain distance from the non-socialist opposition but was not entirely politically passive, can be characterised as being a typical representative of this direction. He shared the legalist position with the Charter opposition, which he himself supported in critical letters sent to the highest authorities of the Czechoslovak Socialist Republic. This is particularly evident in a letter to the Federal Assembly of 28 October 1974 in which Dubček pointed out, above all, the violation of socialist legality, using the example of the systematic restriction of his own personal freedom. However, he also subscribed to the principles of post-January 1968 party policy and especially to the importance of revising Leninist principles, which he still considered to be the starting point and valid for criticism of the ruling party, as was the case in the 1960s. In this letter, among other matters, he stated that:

With the benefit of hindsight, I must reject statements of all kinds and the conclusions of the current party leadership on the revision of Leninism in the principles of party construction. The post-January party leadership highlighted in both theory and practice the Leninist principle of intra-party democracy, without the application of which there can be no talk of a new type of party. This fundamental principle of life

22 The pursuits of (former) reform communists who were stripped of membership in the Communist Party and high political functions but, of course, remained active "in the margins" of society-often within official institutions - is practically not described. This is a group of people who were not involved in the opposition or dissent and believed that they would experience political change that would allow them to re-engage in higher party functions. The majority of them were individuals who looked very warily at the non-communist dissent and independent civic initiatives because it was that emergence, in the eyes of these people, that had thwarted the reform policy of the 1960s. Here, it would be interesting to map out the destinies of some ministers of Černík's government, such as Bohumil Sucharda, František Rehák or Václav Valeš or František Vlasák.

23 Czech national Archives (NA), Čestmír Císař, PhDr., box 7, strojopis Císařovy statě Veletoče Z. Mlynáře, p. 4.

24 NA, Čestmír Císař, PhDr., box 7, strojopis Císařovy statě Veletoče Z. Mlynáře, p. 4.

25 Ibid.

26 Ibid. 
and the party's creative approach to fulfilling its mission was before and is still today being repressed. ${ }^{27}$

In this respect, Dubček, even during the normalisation period, stood consistently on the principles of Leninism; he refused to understand Marxism-Leninism as "a blind dogma, a textbook and primer that prescribes the same recipe and procedure for all communist parties regardless of where they occur" ${ }^{28}$

In relation to the political developments of 1968, this was the correct way for Dubček from the viewpoint of the party's intentions at that time, but like the above-mentioned first stream of reform communists, he believed that the spontaneous social expression of independent activities was the cause of the political crisis and exceeded the boundaries of reform communism. In his letter, he also highlighted the importance of the November resolution of the Communist Party Central Committee of 1968, which arose only as a consequence of military occupation. The essence of the proposed resolution was to be "reform without extremes" while the seeds of opposition political forces (Social Democracy, Club of Committed Non-Party Members, K 231) and the free media were considered to be "extremes" ${ }^{29}$ Dubček characterised this line of the Communist Party as "a synthesis of the positive features of post-January policy with the content and complete and sincere fulfilment of obligations following the Bratislava Declaration and the Moscow Protocol". ${ }^{30}$ In a letter to the Federal Assembly, he also stated that this "retreat from extremes" was "closest to the possibility of political unification of the vast majority of the party and society, and made it possible to lead the party out of a new crisis". ${ }^{31}$

Here, it is understandable that Dubček could not and did not want to exceed the boundaries of the Leninist principle of opposition and take part in independent civic initiatives. Although he reportedly supported Charter 77 privately, ${ }^{32}$ available literature agrees that he did not identify with its "non-socialist" foundations. ${ }^{33} \mathrm{He}$ certainly must have been closer to some of the outcast reform communists who remained "within structures" than, for example, to Mlynár or Havel. With some of the protagonists of the first group-Čestmír Císař, for example-he thus represented the group of so-called waiting opposition.

A similar opposition "line" was taken at first by the editors of Listy, however, during the first half of the 1970s, opinions on cooperation with non-communists began to differ there as well. This ideological dispute culminated in a period of discussions on their approach towards Charter 77 and a possible connection with the non-socialist opposition at home and in exile. While the boldest from the ranks of reformist com-

27 Letter of A. Dubček. In Listy, 1975, Vol. 5, No. 3, p. 10.

28 Among other things, Dubček wrote that "Marxism-Leninism represented a guide to the activities of a communist party when it has its universally valid principles. I mention this because it is difficult for me to be thrown into one bag with the sold-out traitors of the party because, like many others, I looked differently than today's party leadership at the application of party policy at a given stage of development and the method of resolving difficulties and overcoming obstacles in the party and in society." Letter of A. Dubček. In Listy, 1975, Vol. 5, No. 3, p. 10.

29 HOPPE, Jiří. Listopadové plénum ÚV KSČ. In Akademický bulletin Akademie věd České republiky, 2008, Vol. 16 , No. 11 , p. 3.

30 Letter of A. Dubček. In Listy, 1975, Vol. 5, No. 3, p. 10.

31 Ibid, p. 9.

32 A. Dubček a Charta 77. In Listy, 1977, Vol. 7, No. 2, pp. 16-17.

33 BENČÍK, Antonín. Téma: Alexander Dubček. Praha : XYZ, 2012, p. 132. 
munists, the "domestic" opposition activists Zdeněk Mlynář and Jiř́i Hájek—thanks to their commitment to the founding of Charter 77 and personal friendships with many non-communist dissidents-were clearly inclined towards political dialogue and openness, voices were also heard clamouring to hold the political line of the Communist Party of 1968. The most prominent in the argument against Mlynár was Zdeněk Hejzlar, who demanded that the activities of the socialist opposition around Listy focus, above all, on developing a new reform programme within the communist system, otherwise there would be a "catastrophic disintegration of structures". ${ }^{34}$

Like in the case of Dubček, this discussion revealed a contradiction in the view of the Prague Spring among the reform communists inside the Listy editorial circle. While the position inclined towards dialogue with non-communists saw the main benefit of 1968 as linking pressure from the reform part of the party with the forming activism in civil society (i.e. a combination of "top" and "bottom" pressures, as these processes were commonly discussed), advocates of a more cautious approach to reform saw the spontaneous civic manifestations as crossing the boundaries of communist reformism. These discussions often remained internal, and antagonism towards the non-communist opposition during the course of 1968 was never publicly articulated "aggressively", possibly because such a critique of the Prague Spring could have resembled official Normalisation propaganda from the Poučení z krizového vývoje (Lessons Drawn from the Crisis Development). In personal arguments, of course, the dispute over cooperation with non-communists remained one of the main topics of the political opposition's strategy. ${ }^{35}$

The third faction among politically active reform communists was formed by those who gradually focused on strengthening democratic pressure "from below" to revive the "civic tendencies" of 1968. In the new socio-political situation of the second half of the 1970s, these people no longer expected that the main ideological current would further operate continuously within the ideology of the reform communism of the 1960s. ${ }^{36}$ Therefore when Charter 77 emerged, this direction did not consider a return

34 CACCAMO 2008, p. 58.

35 In September 1977, Zdeněk Hejzlar wrote to Mlynář saying that "in 9 years in the West, I have not found any reason why, out of bitterness over the squalor of 'socialism' of Soviet origin, I should run to the camp of capitalists". Hejzlar refused to be part of the "independent opposition", whose basic orientation would not be on the principles of democratic socialism and wanted to continue in the long ideological tradition of attempts to democratise communism, which in his opinion, had been strongly rooted in the Czechoslovak communist movement since the early 1920s "Šmeral" times. Hejzlar saw the reform communist political tendencies as being irreplaceable in the process of opening a path to change in the states of Eastern Europe, because - the same as in the 1960s - they were not aimed at destruction of the existing socio-political and international system. That's why for him, the solution was not to abandon the communist programme in the name of a "general" democratisation of society, but to try again and again to formulate new socialist starting points from the positions of Marxism-Leninism. In the letter to Mlynář, he also stated that he could find "no better tool than his strongly revisionist Marxism, so that I could, in some acceptable way, analyse and explain both the Eastern and Western misery and disarray." At this time, a large portion of the ex-communists were already abandoning the idea of opposition politics as, above all, a communist (or party) policy in the spirit of the reformism of the 1960s. Reform communism was understood more as a potential source of inspiration than as the only valid position. In the circle of the Listy group, Hejzlar was the most systematic critic of the retreat from communist tactics. On the tenth anniversary of the Prague Spring, he wrote in the German magazine $L 76$ that the opening of the "process of change" in Eastern Europe may be "done in the future only by the hands of the Communists themselves. Only opposition from within their ranks can first cross the line of protest and criticism, and set the system in motion." See HEJZLAR, Zdeněk. Reformní komunismus nepatří minulosti. In Listy, 1978, Vol. 8, Special Issue 1968-1978 in Retrospect, p. 38; Originally the article was published in a more comprehensive state in $L 76$ and entitled "Je reformní komunismus ve Východní Evropě překonán?".

36 NA, Zdeněk Mlynář, box 4, Strojopis Mlynářovy studie O politických zkušenostech levicových intelektuálů v Československu. Př́spěvek v diskuzi na téma: Intelektuálové a politika v Kolíně, 17 September 1977. 
to party structures as a realistic political goal, though this changed for some at the end of the 1980s during the perestroika period. Members of this third group were the active signatories of Charter 77. In their non-Chartist activities, they were still actively taking part in the international communist or socialist movement and were trying to "apply the socialist viewpoint within the Czechoslovak opposition movement, which is emerging 'from below' as pressure from non-communist political forces in the regime, attempting for democratisation". ${ }^{37}$ This current rejected the ongoing practice of normalising the Communist Party, though it clearly spoke in favour of maintaining the socialist system in Czechoslovakia. It is only this group that historians and period documents refer to as "ex-communists in the Charter" ${ }^{38}$

The ex-communists in the Charter spoke about a "synthesis of diverse experiences from practice in the existing system", and especially at the beginning saw in the Chartist critique "a continuation of democratisation and humanisation efforts in a renewal of the process of 68". The political experience of the ex-communists of the 1960s, which "no one else has in the way of life experience and cannot have" was to play an important role here. ${ }^{39}$ Miroslav Kusý, another representative of the third way, described the continuity with the renewal process in the sense of "an effort to ensure the legal and human security of the civic and human existence of every person in this republic" ${ }^{40}$ Reform communists who decided to cooperate with the non-communist opposition joined the common opposition platform with a sense of continuity with the year 1968 . They viewed it primarily in the efforts to "constitute a legal consolidated civil and civilised human society", exactly the premise on which it was newly constituted in the nascent Chartist dialogue.

It is necessary to point out that the reform communists remained discredited in the eyes of some of the exile and domestic opposition because of their past involvement. As a result, discussions on their credibility were under way. Petr Placák gave a detailed description of a dialogue between ex-communists and Christian activists on the grounds of the lay organisation Opus Bonum. However, Placák also describes the strong criticism that prevailed in exile against the reform communists, primarily from

37 NA, Zdeněk Mlynář, box 4, Strojopis přednášky (uvedeno pouze “pro sborník v Madridu”) Deset let po "pražském jaru" v Československu, pp. 15-16, June 1978.

38 In regard to the definition of the term "ex-communist" See OTÁHAL, Milan. Opoziční proudy v české společnosti. Praha : Ustav pro soudobé dějiny AV ČR, 2021, pp. 24-39; Among the important period contributions of the dissident discussion on the participation of ex-communists in the Charter see also MLYNÁ $\check{R}$, Zdeněk. Exkomunisté a křestané. In Studie, 1978, No. 60, pp. 414-428; MEDEK, Ivan: Křestané a exkomunisté nejen v Chartě 77. In Studie, 1979, No. 62, pp. 147-149; ZVĚǨINA, Josef: Nežít v nenávisti (Přátelům i nepřátelům). In Listy, 1980, Vol. 10, No. 1, pp. 43-46; Probably the most detailed contribution on the clarification and definition of the term "ex-communists" and on the reflection of their participation in Charter 77 was the thoughts of Miroslav Kusý in May 1982: "Ex-communists and the Charter" published in Listy magazine. Kusý understood the activities of the ex-communists as a logical consequence of the "humanisation efforts of 1968". He wrote: "That core of ex-communists who declare themselves to be the legitimate heirs to the renewal process of 68 therefore had to, of course, and with the deepest inner conviction, be incorporated into the Charter 77 civic initiative movement. The effort to constitute a legally consolidated civil and civilised human society in our country and an effort to ensure the legal and human security of the civic and human existence of every person in this republic naturally connects them with the Charter. It should not be a fullfledged homeland only for the communists, only for the privileged, but for everyone who was born here, who lives here and has resolved to continue living here. Participation in Charter 77 logically fully follows for these ex-communists from their basic democratisation and humanisation efforts in the revival process of 68. It is a continuation of it at today's level using today's means." KUSÝ, Miroslav. Exkomunisti a Charta. In Listy, 1982, Vol. 12, No. 2, pp. 31-36.

39 MLYNÁ̌̌, Zdeněk. Charta 77 po dvou letech (druhá část). In Listy, 1979, Vol. 9, No. 2, p. 9.

40 KUSÝ 1982, p. 35. 
the post-February 1948 Christian-oriented exile. He notes here, among other things, a statement by journalist and editor of Radio Free Europe, Jaroslav Dresler, who rejected the idea of developing an exile dialogue with ex-communists who were, in his words, "disqualified" from working in a democratic society:

I believe that dialogue with some former leaders of the Czechoslovak communists is, at the very least, reckless. These people-not collectively, of course, but each individually-committed an offence against democracy and especially, violated the Czechoslovak constitution and its laws, including the so-called socialist legality. Jiří Pelikán and Zdeněk Hejzlar had a share in the purges at universities and negatively affected the lives of ten thousand young people. Zdeněk Mlynár was still defending communist censorship in the spring of 1968 and signed the Moscow Protocol. A.J. Liehm was a reporter in the Slánský trial. Pavel Kohout was one of the main proponents of Stalinism in literature. ${ }^{41}$

\section{Obroda (Renewal): An Attempt to Rehabilitate Reform Communism in the Perestroika Period}

At the end of the 1980s, reformist communist opinions could no longer be ascribed to all former reform communists, and certainly not to all who joined the newly formed movement Obroda: Klub za socialistickú prestavbu (Renewal: The Club for Socialist Restructuring), which consciously represented reform communism and the legacy of the Prague Spring following the reform ideas of the 1960s. Of course, even in the environment of Obroda, at the end of the 1980s, there was a clear trend towards views of a rather social democratic type, embodied at that time by Western Socialist International. ${ }^{42}$ The circle of people who went on to form Obroda began to take shape in 1987 as a reaction to the muted response to perestroika in Czechoslovak politics. It was made up of almost exclusively former reform communists and functionaries from the Prague Spring; merely a certain segment of those who had maintained contact with one another throughout Normalisation. The most prominent representatives among them were, for example, Miloš Hájek, Vojtěch Mencl, Václav Kural and Josef Domaňský. In its February 1989 programme statement, Obroda supported democratic socialism, Gorbachev's perestroika and Euro-communism:

We want, in our efforts, not only to take up the legacy of the past and the ideas of our democratic socialist renewal process of 1968 and today's reconstruction in the Soviet Union, but also the experience and successes attained on behalf of the people by socialist, democratic and some communist parties in the western part of our continent. ${ }^{43}$

The strategy of the former reform communists was mainly to appeal to Communist Party leadership in the area of democratising society. Aside from Gorbachev's perestroika, Obroda directly avowed the legacy of the 1968 reform programme, which in their opinion, corresponded to socialism based on the principles of humanity and

41 PLACÁK, Petr. Lidská práva aneb Člověčenství. Charta 77 na půdě exilové organizace Opus bonum. In Pamět’ a dějiny, 2016, No. 4 , p. 34.

42 TUMA, Oldřich. Historický úvod. In KOKOŠKOVÁ, Zdeňka - KOKOŠKA, Stanislav. OBRODA: Klub za socialistickou přestavbu. Dokumenty. Prague : Maxdorf, 1996, pp. 9-14.

43 Prohlášení př́ípravného výboru Klubu za socialistickou přestavbu OBRODA (2/1989). In KOKOŠKOVÁ KOKOŠKA 1996, pp. 45-51. 
democracy and attempted to "remove the bureaucratic system directing the society uncontrollably". 44

Obroda saw itself as a movement that would try to engage in a dialogue with all emerging civic initiatives and informal groupings, but also with members of "all" political parties $^{45}$, presenting itself as a "constructive opposition". ${ }^{46}$ The position of Obroda in the first half of 1989 is relatively ambiguous. Jiří Suk described the approach as "oscillating between loyalty and activism". ${ }^{47}$ Obroda expressed a willingness to cooperate with both new independent initiatives as well as the Communist Party. In the Statement of the Preparatory Committee of the Club Obroda, the club announced that it was prepared for dialogue with representatives of the Communist Party, in which it saw "a glimpse and the beginning of a broad dialogue between official institutions and all independent groups" ${ }^{48}$ However, the statement also commented on cooperation with emerging independent political movements, which it labelled as partners "with a significant share in the creation of public opinion and the new, coming, popular state policy". ${ }^{4}$

Although Obroda demonstrated a willingness to cooperate across the emerging political spectrum, in the Statement of the Preparatory Committee, the organisation clearly defined itself against the rehabilitation of liberal-democratic principles:

We reject the efforts of defeatists to write off socialism in the name of new liberalism, a "pure" democracy, "absolute" freedom and the like, which have no chance in real life and wander in the realms of fantasy. It is impossible to solve the crisis of Stalinism with the liquidation of socialist ideology, but with the liquidation of false ideology and its replacement by socialist humanism. ${ }^{50}$

According to one Obroda member, Luboš Kohout, the political pluralism that Obroda proclaimed in its statements represented the "position of socialist, social-democratic and some communist parties" ${ }^{11}$ Such an approach contravened the liberal conception of Western European political plurality as a competition between independent political entities. In the end, Kohout himself wrote that Obroda does not suffer from "frequent illusions about the perfection of democracy as developed in Western or Northern Europe or North America" ${ }^{52}$

The rejection of Western-style liberal democracy—an "outdated" model of democracy for the reform communists-was also associated with critical attitudes towards some independent civic initiatives. Their demands, which openly postulated the transition to a party pluralistic system, were perceived in the eyes of Obroda members as inadequate in the context of the political situation at the time. Historian and Chartist Milan Hübl expressed scepticism regarding programmes and statements that relied on the rapid removal of the Communist Party, or its leadership role. He perceived non-communist

44 KOKOŠKOVÁ - KOKOŠKA 1996, pp. 45-51.

45 Ibid, p. 116.

46 TŮMA 1996, pp. 9-14.

47 SUK, Jiř́i. Zlom mezi “totalitou” a "demokraciiß". Československý rok 1989 v alternativách. In Soudobé dějiny, 2009, Vol. 16, No. 4, p. 584.

48 SUK 2009 , p. 584.

49 Archive of ĆSSD (AČSSD) Obroda, box 3, Sdělení přípravného výboru klubu Obroda, p. 3, 5 April 1989.

50 AČSSD, Obroda, box 3, Sdělení př́pravného výboru klubu Obroda, p. 3, 5 April 1989.

51 KOHOUT, Luboš. Prohlášení Obrody a její kritikové. In Ze zásuvky a bloku, 1989, Vol. 6, No. 21 , p. 58.

52 KOHOUT 1989, p. 58. 
manifestos as unrealistic and advocated that the opposition unite on a platform advancing the principles of a Czechoslovak perestroika, an approach prevalent in the Obroda Club:

Thus far, no one has stepped before the local public with a realistic programme of gradual transformation which would, in spite of the rigidity of power and its structures, present a viable path. [...] Although, as we mainly hope, the course linked with Gorbachev's name will prevail, it will not be easy to activate it in our country. The irreplaceability of Dubček and those around him will again be shown, because only they can build bridges to Gorbachev and positively influence the refining the opinions within power structures. ${ }^{53}$

In a release from April 1989, Why Obroda Was Founded, Miloš Hájek argued for a similar direction. He cautiously defined himself against the Hnutí za občanskou svobodu (The Movement for Civil Liberties), which was associated with both socialists and non-socialists. Hájek saw this as a possible weak point for the development of more precise political positions. In his opinion, the aim at the given moment should be mainly a "solid and formed socialist opposition", ${ }^{44}$ which would rehabilitate the original ideals of socialism in the eyes of Czechoslovak citizens. Such opposition was to prevent the democratisation process from "taking on an explosive nature", which in the language of the reformist communists meant, above all, the collapse of socialist political structures.

The programmes and declarations of Obroda in the spring of 1989 demonstrate a certain conceptual confusion, likely based on a murky understanding regarding the leading role of the Communist Party and the Communist Party in general. Certainly, differing opinions of members were expressed on the degree of cooperation with the Communist Party, its role in the democratisation process as well as possible constitutional changes. In further theses, Obroda sketched out a constitutional framework in which it "mixed all the main types of democratic representation-plebiscite, parliamentary and presidential-without making it clear how they might work together" ${ }^{55}$ They spoke ambiguously about the National Front, on one hand referring to democratic principles that exclude any monopoly and permit all political associations to seek the trust of citizens, and in the same report, speaking about the systems of the National Front, which can play a positive role in the process of preserving democracy. The National Front was understood as a "democratic and socialist partnership cooperation of independent political entities, i.e. parties and interested organisations". ${ }^{56}$ The political arrangement in which Obroda likely saw the most realistic way of fulfilling its demands was the postwar system of so-called limited democracy between 1945-1948, which Kohout called a "specific national and democratic path to socialism without the so-called dictatorship of the Soviet-type proletariat" ${ }^{57}$ It seems that for the reform communists, the post-war political system of the Czechoslovak Third Republic, critical of liberal political principles, was a boundary they had no intention of crossing historically and in it, they saw a higher stage of historical-political development that transcended liberal (bourgeois)

53 HÜBL, Milan. Záhořovo lože a jak z něj. In Listy, 1989, Vol. 19, No. 2, p. 13.

54 HÁJEK, Miloš. Proč vznikla Obroda. In Listy, 1989, Vol. 19, No. 4, p. 21.

55 SUK, Jiří. Demokracii pro všechny! Jenže jakou? Parlamentní demokracie v úvahách opozičních skupin na sklonku 80. let (draft of an article to be published in 2021).

56 KOHOUT 1989, p. 57.

57 KOHOUT 1989, p. 57. 
democracy. On 3 December 1989, Čestmír Císař declared in the Bergedorf Discussion Club at the Forum Hotel in Prague among other things, "Those who think that our development can return to the situation before 1938 are dreamers. [...] So, don't expect a possible return to capitalism in terms of the economy." ${ }^{38}$

Jiří Suk precisely described the main problem associated with the political imagination of Obroda:

If someone wants political pluralism and the division of power, he is already abandoning socialism as a permanently shared and unchangeable reality, because people can freely choose such social practices and adopt such laws that gradually establish another type of government, such as privatising state-owned enterprises or cooperatives, et cetera. ${ }^{59}$

Obroda thus found itself in the same dilemma as the reform communists in 1968; appealing to political pluralism and the opportunity of the individual to freely decide, and at the same time believing that the socialist establishment would remain preservedassuming that socialism will automatically be understood as the indisputable foundation of the political system.

As with other independent initiatives, the events of November 1989 represented an important moment for the reform communists as the long-awaited "mass movement" of the people, who can actively participate in the process of democratisation of the socialist system and the associated transformation of the Communist Party, finally materialised. The Analytical Group of Obroda called the mechanism of the spontaneous establishment of civic forums a "revolutionary process, not reform", which is "an expression of the spontaneous will of the people". ${ }^{60}$ It appealed to the Občanské forum (Civic Forum, OF) to be open to as many entities as possible that wish to share in the democratic changes, such as representatives of the Revoluční odborové hnutí (Revolutionary Trade Union Movement) or the democratic communists. At the end of November, the leadership of the Communist Party, attempting to salvage its position, invited Obroda, specifically Vojtěch Mencl, Čestmír Císař and Josef Domaňský, to a joint meeting. Obroda thus returned to a schizophrenic position stemming from its efforts to balance between preserving a socialist establishment and the demand for unrestricted democratic free elections. It was part of the Civic Forum, though at the same time acted as an independent political entity with its own interests.

As a result, a considerable amount of distrust began to be felt within the Občanské forum towards Obroda, also because future Prime Minister Marián Čalfa promoted Čestmír Císař to the government during the negotiations with the Občanské forum. As recalled by Petr Pithart, the topic of reform communism was opened within the Občanské forum during this meeting and the majority of members present expressed negative and distrustful opinions because they did not expect such a quickly organised and united group promoting its own political agenda. ${ }^{61}$ The credibility of

58 Cited by SUK 2009, p. 585.

59 SUK, Jiř́i. Demokracii pro všechny! Jenže jakou? Parlamentní demokracie v úvahách opozičních skupin na sklonku 80. let (draft article, to be published in 2021).

60 AČSSD, Obroda, box 3, Strojopis prohlášení O politice 17. 11. KSČ jako moc - občanská společnost jako opozice, 26 November 1989.

61 PITHART, Petr. Devětaosmdesátý. Vzpomínky a přemýšlení: Krédo. Praha : Academia, 2009, p. 166. 
the so-called sixty-eighters was not helped by the "legendary" television appearance of Zdeněk Mlynár, where he criticised the OF policy, defended the importance of the Communist Party's role in democratic transformation and the communist Prime Minister Ladislav Adamec's 15:5 government (fifteen of the twenty government positions would remain for the Communist Party). ${ }^{62}$ Even though Obroda distanced itself in writing from Mlynář̀s television appearance the next day, ${ }^{63}$ the distrust and aversion towards the reform communists rose within the OF. Leading representatives of the Civic Forum who did not have a communist past refused to let those from Obroda into the room during their negotiations considering them to be "traitors" ${ }^{4}$ Understandably, the voices of the former reform communists who operated under Charter 77 in the OF expressed doubts about such behaviour. However, it is evident from the recorded transcripts of the OF meetings that these "Chartist ex-communists" (e.g. Zdeněk Jičínský, Miloš Hájek or Rudolf Slánský, Jr.) were perceived very differently than people who were not involved in the Charter during the 1970s and 1980s. ${ }^{65}$

Vigilance can also be rather clearly seen in the records of the OF meetings where Václav Havel clearly rejected cooperation with Obroda and expressed considerable opposition to the movement and the reform communists:

I think that thanks to Zdeněk Mlynář, Mr. Dubček was also written off from his candidacy for anything. Because of that, Mlynár is the reason we lost, or-not to speak for others-I lost confidence in the reform communists so much that I think that if there are two of them, I'll return to being a dissident and writing plays and having fun with Captain Čermák in his interrogation room and I will have peace of mind. ${ }^{66}$

Havel even refused to negotiate politically with Obroda, which according to him was:

Worse than the party. Those from Obroda are traitors, while those from the party are partners, that Mohorita. I will talk to Urbánek at any time, but I hang up the phone on Mlynár when he calls me [...] And he asked me (Josef Krejčí-secretary of the National Front), 'Do you want Obroda there?' And I said, 'I'm not going anywhere if Obroda is there.' Obroda is, I don't know, five and a half people? It's like a party [...] Why should we exclude the Party of Slovak Revival from negotiations? Because it is ridiculous to us. And why should we negotiate with the presence of this Obroda as if it represented someone? And what's more, I personally feel that they are traitors ${ }^{67}$

62 In his study of Zdeněk Mlynár. Alessandro Catalano presents the memory of the last Secretary General of the Communist Party, Karel Urbánek, "He suddenly appeared in my office, without notice. He came to ask me to order that his son be released from prison. [...] After a short exchange of opinions, I made him an offer to appear on television in defence of democracy and I would help with his son. He reacted with great surprise, 'After everything that has happened, you want me to appear on television in defence of the Communists?' 'I really couldn't ask for that, but you can speak out against the media persecution of those who have done nothing wrong except having a different opinion on the social organisation of the state and on the period of building socialism.' 'Mr. Secretary General, you are a businessman, but I would do anything for my son, I will appear on television.' Zdeněk Mlynár appeared on television, amply funded, and his son was released. To my regret, however, it hurt him in the period that followed." CATALANO, Alessandro. Zdeněk Mlynář a hledání socialistické opozice. Od aktivní politiky přes disent k ediční činnosti v exilu. In Soudobé dějiny, 2013, Vol. 20, No. 3, p. 281.

63 AČSSD, Obroda, box 3, Stanovisko klubu za socialistickou přestavbu Obroda, 8 December 1989.

64 HÁJEK, Miloš. Pamět české levice. Praha : Ústav pro soudobé dějiny AV ČR, 2012, pp. 306-312.

65 HÁJEK 2012.

66 SUK, Jiří. Občanské fórum: listopad-prosinec 1989. 2. díl. Dokumenty. Brno : Doplněk, 1998, p. 140.

67 SUK 1998, pp. 139-140. 
Thanks to this exclusion, the political careers of some sixty-eighters began to head towards renewed convergence with the post-1989 Communist Party of Bohemia and Moravia (KSČM) and a search for a new political position other than the democratic centre occupied by the Civic Forum. Obroda vainly sought a place of its own within the emerging political spectrum, though it still viewed itself as a club rather than a political party and saw its future more in cooperation with one of the left-wing parties in favour of democratic socialism. It did not initially hamper cooperation with the Communists or above all, with the reform-oriented Democratic Forum of Communists. ${ }^{68}$ However, the attitudes of the former sixty-eighters-especially functionaries from the spring of 1968, with which Obroda mostly associated-towards the KSČ and later the KSČM, were relatively complicated, even though before November 1989, the majority of them were inclined (as part of the reconstruction) towards cooperation-or at least dialogue-with the KSČ. However, after the collapse of the communist system, they saw no future in reform communism.

Most of the actors of the Prague Spring had broken away from the normalising communist party under relatively unfavourable circumstances-either they withdrew from the Communist Party as a protest against the occupation, or they were later expelled or expunged. For them, the post-November KSČM thus represented a totally different political entity than the "Prague-spring" Communist Party, ideologically and personally, and in its current form, they did not see it as a party with the potential to fulfil the ideals of democratically oriented socialism in the future. There was practically no room for common discussion here, though individuals tried to incite such talk, for example, within the Levý Blok (Left Bloc, LB) electoral coalition, which for a brief time became the hope for some former reform communists to restore the socialist platform within the Czech left-wing scene.

Its weakness, however, lay in the fact that these were predominately people with a communist past; nearly all of its members and functionaries had been members of the Communist Party at some point in their lives, although Mlynár emphasised that LB members considered the former Communist Party to be undemocratic and refused to support it. ${ }^{69}$ The LB failed in its efforts to address a wider audience and failed to gain a more prominent place in the political spectrum. No additional significant political engagement since the 1960s came.

Yet, these post-communist socialists derived from the reform communism of the 1960s (Pelikán, Císař, Hájek, Mlynář, Kosík) left a relatively distinctive imprint in the Czech public discourse of the 1990s. They became early critics of unregulated capitalism and the new politics of memory. Although the sixty-eighters were an internally diverse group affected by years of disputes and conflicts, it was in fact the post-communist

68 HÁJEK, Miloš. Místo Obrody v dnešním politickém spektru. In KOKOŠKOVÁ - KOKOŠKA 1996, pp. $194-195$.

69 Zdeněk MLYNÁŘ wrote, "Yes, they do not hide it and they are not ashamed of it, because they split with the anti-democratic ideology and practices of the former KSC, and did so not only in words, but in deeds. Some of them long ago, around 1968, others-mainly those who were still children during the Prague Springnot until around 1989. In their programme, however, at the same time they reject the purposeful contempt, simplification or silencing of our history and declare that the collapse of 'real socialism' for them does not mean that they cease supporting humanist and socialist values and goals and seek better alternatives to development than traditional capitalism offers." Quoted from MLYNǍR, Zdeněk. Levý blok není KSČM. In MLYNÁ Ř, Zdeněk. Proti srsti. Praha : Periskop, 1996, p. 188. 
politics of memory that brought them back again to the same ship and unified their arguments. The new official version of post-war history resulted in the leading communist representatives of the Prague Spring belonging, according to the law, to the same political category as the normalisation elite (Husák, Bilak or Jakeš), which helped to liquidate any democratic achievements of 1968. No wonder then that it was the sixty-eighters who first called for the need to revise this interpretation.

\section{Conclusion}

The story of Zdeněk Mlynářss return to Czechoslovakia is an example of the bitter experience that was typical for many Czechoslovak socialists in the 1990s. Mlynár returned to Czechoslovakia convinced that he would play an important role in the political transition to democracy, mainly due to his knowledge of the internal functions of political institutions. It soon became clear, however, that similarly to many former communist officials of the spring of 1968, Mlynár was not seen as a fully credible political figure. The new political course was set in a very different direction than the one he had sought during the entire period of normalisation. He had no choice but to become an opposition-in this time legal-critic of the new policy and, as he himself declared in 1989, an advocate of the "honest people in the Communist Party", who in his mind "ended up politically in the dock". Mlynár said of this, "I was one of the initiators of Charter 77 in 1977 because I shared the opinion that every accused needs an advocate. Without one, there can be no objective assessment of guilt. Without that, there can be no rule of law." ${ }^{70}$ Thus, even after November 1989, Mlynár took the position of a "legalist critic" and became a vocal opponent of the new memory and history laws (mainly the Lustration Act and Act on Illegality of the Communist Regime and on Resistance Against It).

The end of Mlynáŕs career was marked by a controversial political indictment, in which he was accused of treason for organising the procession of tanks into Czechoslovakia in 1968 and his complicity in the founding of the pro-Soviet "workers' and peasants' government". Mlynár thus transformed from an advocate of the rule of law into an actor in the political process. Even though the charges were dropped due to expiration of the twenty-year statute of limitations, Mlynár was crushed by the accusations. Thus, to a certain extent Mlynár's political failure in the first half of the 1990s and his subsequent death in 1997 symbolised-at least temporarily—the fate of Czech socialist politics in this period.

In this text, I have shown the historical genesis of political distrust of the so-called sixty-eighters-communist officials from the Prague Spring. Though a large portion of the group actively took part in the democratic opposition or went into exile, after 1989 , society still largely perceived them as (reform) communists and efforts to renew cooperation with the KSČM certainly did not add to any political trust from the rightwing and liberal media. Their political failure, however, also needs to be seen in the broader context of ideological development after 1989. To defend the idea of socialism anywhere in Central Europe in the 1990s meant choosing a certain type of political isolation. The failure of socialism in Central Europe after 1989 was not, understandably,

70 MLYNÁ̌̌, Zdeněk. Tak takhle tedy také ne! In Rudé právo, 14 December 1989, p. 1. 
due only to social distrust and the weakness of political programmes. The effort to formulate a left-wing critique of post-1989 liberal democracy was not a type of criticism that would become generally accepted in the 1990s, namely because of the party history of those who spoke it. In a time carried away by the "triumph of liberalism", many influential intellectuals declared the "death of socialism" and even more warned of the danger of any "third way".71 In a situation where Marxism and socialism had completely lost all political power, the concept of (democratic) socialism ended up in the fringes of public political vocabulary, with a great part of society rejecting the idea of the socialist left as a dangerous remnant of the communist dictatorship.

71 For example: DAHRENDORF, Ralf. The Strange Death of Socialism. In Studies: An Irish Quarterly Review, 1990, Vol. 79, No. 313, pp. 7-17; FUKUYAMA, Francis: The End of History? In The National Interest, 1989, Winter 1989/1990, No. 16, pp. 3-18.

\section{Cite:}

ANDĚLOVÁ, Kristina. The Genesis of Political Distrust Towards the "Sixty-Eighters" in Czech Politics Over the Course of 1989. In Forum Historiae, 2021, Vol. 15, No. 2, pp. 86-103. ISSN 1337-6861. DOI: https://doi. org/10.31577/forhist.2021.15.2.7

Kristina Andělová

Ústav pro soudobé dějiny AV ČR, v.v.i.

Puškinovo náměstí 447/9

16000 Praha 6

email: andelova@usd.cas.cz

https://orcid.org/0000-0001-6295-4115 